\title{
Desulfonatronum cooperativum sp. nov., a novel hydrogenotrophic, alkaliphilic, sulfate-reducing bacterium, from a syntrophic culture growing on acetate
}

Correspondence

Tatjana N. Zhilina zhilinat@mail.ru
The anaerobic decomposition of organic matter is performed by fermenting bacteria and typically leads to acetate and $\mathrm{H}_{2}$ as major products. In alkaliphilic microbial communities, several micro-organisms that utilize molecular hydrogen are described, including sulfate-reducing bacteria, which often dominate in alkaliphilic environments where the sulfur cycle is well developed (Zavarzin et al., 1996; Gorlenko et al., 1999). In contrast to hydrogenutilizing micro-organisms, very little is known about microorganisms that consume acetate in soda lakes or other alkaline habitats (Zavarzin \& Zhilina, 2000). The first evidence for acetate utilization coupled to sulfate reduction

Published online ahead of print on 3 December 2004 as DOI 10.1099/ ijs.0.63464-0.

The GenBank/EMBL/DDBJ accession number for the 16S rRNA gene sequence of strain Z-7999' is AY725424. was observed in cellulose-decomposing enrichment cultures obtained from such habitats (Kevbrin et al., 1999). Sulfidogenesis on acetate occurred rapidly, although no specialized acetate-consuming, alkaliphilic sulfate reducers have been isolated so far. Members of the genus Desulfobacter, which show a rapid turnover of acetate and are found in brackish, marine and hypersaline habitats, seem to be absent from these habitats.

An acetate-utilizing, sulfate-reducing enrichment culture obtained from deposits of the local soda lake Khadin, located near Kysil-city, Tuva, Russia, was found to contain several types of straight rods and vibrios. The rods present in the enrichment were unable to grow on acetate and showed no reduction of sulfate. Therefore, it was concluded that utilization of acetate might be carried out by a syntrophic association, i.e. an acetate-oxidizing bacterium 
that produced molecular hydrogen and a hydrogenotrophic sulfate-reducing bacterium producing $\mathrm{H}_{2} \mathrm{~S}$. To verify this hypothesis, it was necessary to isolate the hydrogenotrophic member of this association in pure culture.

Here, the isolation and characterization of a novel hydrogenotrophic, alkaliphilic, sulfate-reducing species, Desulfonatronum cooperativum sp. nov., that is able to participate in acetate decomposition in syntrophic co-culture are described. In addition, this novel species is able to grow with lactate as an electron donor. For isolation of alkaliphilic, sulfate-reducing bacteria, samples of anoxic deposits and water from the soda lake Khadin were used. The $\mathrm{pH}$ of water at the sampling site was $9 \cdot 5$, salinity was $10 \mathrm{~g} \mathrm{l}^{-1}$ and alkalinity $\left(\mathrm{Na}_{2} \mathrm{CO}_{3}+\mathrm{NaHCO}_{3}\right)$ was $450 \mathrm{mg} \mathrm{l}{ }^{-1}$.

The initial enrichment was obtained using acetate as the only carbon source in an anaerobically prepared basal medium of the following composition $\left(\mathrm{g} \mathrm{l}^{-1}\right): \mathrm{NH}_{4} \mathrm{Cl}, 0 \cdot 5$; $\mathrm{KH}_{2} \mathrm{PO}_{4}, 0 \cdot 2 ; \mathrm{MgCl}_{2} \cdot 6 \mathrm{H}_{2} \mathrm{O}, 0 \cdot 1 ; \mathrm{KCl}, 0 \cdot 2$; yeast extract (Difco), $0 \cdot 2 ; \mathrm{Na}_{2} \mathrm{CO}_{3}, 6 \cdot 5 ; \mathrm{NaHCO}_{3}, 3 \cdot 25 ; \mathrm{NaCl}, 4 \cdot 18$; $\mathrm{Na}_{2} \mathrm{SO}_{4}, 3 \cdot 0$; sodium acetate, $3 \cdot 0$; and $\mathrm{Na}_{2} \mathrm{~S} .9 \mathrm{H}_{2} \mathrm{O}, 0 \cdot 5$. The medium also contained a trace element solution $\left(1 \mathrm{ml} \mathrm{l}^{-1}\right.$; Kevbrin \& Zavarzin, 1992). The $\mathrm{pH}$ was maintained at $10 \cdot 0$ with a sodium carbonate/sodium bicarbonate buffer before autoclaving. The medium was dispensed into $120 \mathrm{ml}$ flasks with screw caps and the headspace $(70 \mathrm{ml})$ was filled with $\mathrm{N}_{2}$ at atmospheric pressure. Inoculated flasks were incubated at $35^{\circ} \mathrm{C}$.

Light and electron microscopy were carried out as described previously (Zhilina et al., 1997). For determination of utilization of various compounds, formate in the medium was replaced by the following: organic growth substrates (peptides and organic acids) at a concentration of $3.0 \mathrm{~g} \mathrm{l}^{-1}$ $(\mathrm{w} / \mathrm{v})$; alcohols $\left(5 \cdot 0 \mathrm{ml} \mathrm{l}^{-1}\right)$; or molecular hydrogen $(100 \%$ gas phase). The ability to ferment sugars was tested using the basal medium without sulfate and formate. Utilization of various electron acceptors (sulfate, thiosulfate, sulfite, dithionite, nitrate, nitrite, fumarate and elemental sulfur) was tested as described previously (Zhilina et al., 1997). Lithotrophic growth with molecular hydrogen was tested on medium with the same mineral composition in the absence of yeast extract with acetate $\left(0 \cdot 16 \mathrm{~g} \mathrm{l}^{-1}\right)$ as carbon source. Cultivation was performed in $60 \mathrm{ml} \mathrm{screw}$-capped flasks containing $10 \mathrm{ml}$ medium. Headspace $(50 \mathrm{ml})$ was filled with $100 \%$ hydrogen.

Temperature, $\mathrm{pH}$ and $\mathrm{NaCl}$ concentration requirements were tested using the basal medium with formate as electron donor and sulfate as electron acceptor. The $\mathrm{pH}$ and $\mathrm{NaCl}$ ranges for growth were determined at $35^{\circ} \mathrm{C}$ as described previously (Garnova et al., 2003). To determine whether sodium carbonates were required for growth, carbonates were replaced with $\mathrm{NaCl}\left(15 \mathrm{~g} \mathrm{l}^{-1}\right)$ and a $\mathrm{pH}$ of $9 \cdot 0$ was obtained with $20 \mathrm{mM}$ Tris/base buffer $\left(\mathrm{p} K_{\mathrm{a}}\right.$ of $\left.9 \cdot 0\right)$.

Bacterial growth was monitored by direct cell counting under a phase-contrast microscope (Reichert Zetopan), by measuring sulfide in the growth medium (Trüper \& Schlegel, 1964) and by estimating the increase in OD at $600 \mathrm{~nm}$ (Specol-10; Carl Zeiss). DNA was isolated and purified as described by Marmur (1961). The G $+\mathrm{C}$ content was determined by the thermal denaturation method (Owen et al., 1969); Escherichia coli K-12 DNA was used as a standard. For DNA-DNA hybridization with the type species Desulfonatronum lacustre $\mathrm{Z}-7951^{\mathrm{T}}$, DNA was obtained by a 'nick-translation' reaction based on $\left[{ }^{3} \mathrm{H}\right]$ cytidine (Rigby et al., 1977). 16S rRNA gene amplification, sequencing and sequence analyses were done as described previously (Kuever et al., 2001). The sequence was loaded into the $16 \mathrm{~S}$ rRNA sequence database of the Technical University of Munich, Germany, using the ARB program package (Ludwig et al., 2004). The tool ARB_ALIGN was used for sequence alignment, visually inspected and corrected manually. Tree topologies were evaluated by performing maximum-parsimony, neighbour-joining and maximum-likelihood analyses using a termini filter. Only sequences with at least $1200 \mathrm{nt}$ were used for calculations. The tree contains all sequences of species with validly published names of the genera Desulfovibrio, Bilophila, Lawsonia and Desulfomicrobium. Species designations and GenBank/EMBL/DDBJ nucleotide sequence accession numbers (type strains) that were not included in the ARB database are as follows: Desulfonatronovibrio hydrogenovorans, X99234; 'Desulfothermus naphthae' (strain TD3), X80922; Desulfonauticus submarinus, AF524933; Desulfonatronum thiodismutans, AF373920; and Desulfonatronum lacustre, AF418171.

After 30 days incubation, utilization of acetate coupled to sulfide production was obtained. Several types of straight rods (some of them spore-forming) and small vibrioid cells were observed in the medium. After several successive transfers in acetate-containing basal medium, the enrichment was serially diluted in roll-tubes using the same medium solidified with Bacto-agar $\left(2 \cdot 0 \mathrm{~g} \mathrm{l}^{-1}\right)$. Several types of colonies appeared after 10 days incubation and were transferred to the liquid basal medium, but none of them grew with acetate. This phenomenon could be explained by syntrophic oxidation of acetate by the alkaliphilic community, which includes at least one sulfate-reducing bacterium, possibly serving as a hydrogen or formate scavenger. The enrichment was serially diluted in rolltubes with the same medium in which acetate was substituted by formate $\left(3 \mathrm{~g} \mathrm{l}^{-1}\right)$. Single, slightly lens-shaped, rose colonies, $0 \cdot 1-0 \cdot 2 \mathrm{~mm}$ in diameter, appeared after 7 days incubation and were transferred to the liquid basal medium with formate as electron donor. All isolates obtained had the same phenotypic characteristics. One of them, designated strain Z-7999 , was selected for detailed characterization.

Cells of strain Z-7999 ${ }^{\mathrm{T}}$ were small vibrioids, $0 \cdot 4-0 \cdot 5 \mu \mathrm{m}$ in diameter and $1 \cdot 0-2 \cdot 5 \mu \mathrm{m}$ in length (Fig. 1a). Single cells were observed during the exponential phase of growth. In the stationary phase, cells occurred in chains (three to ten 


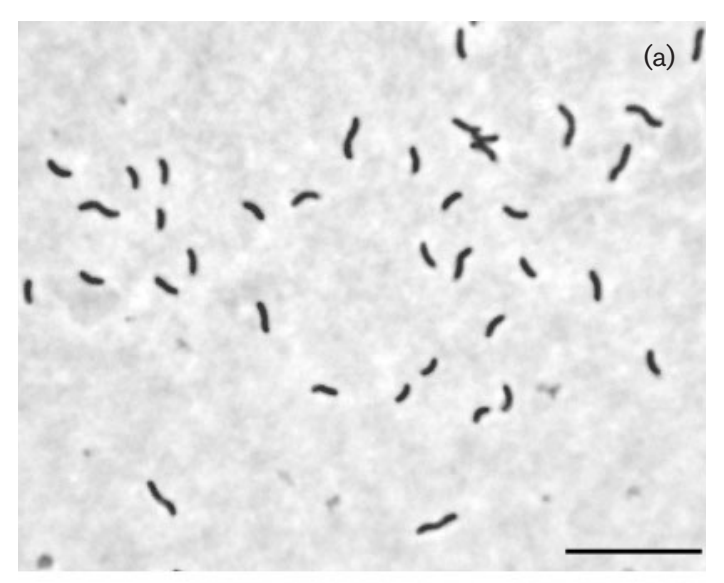

(b)

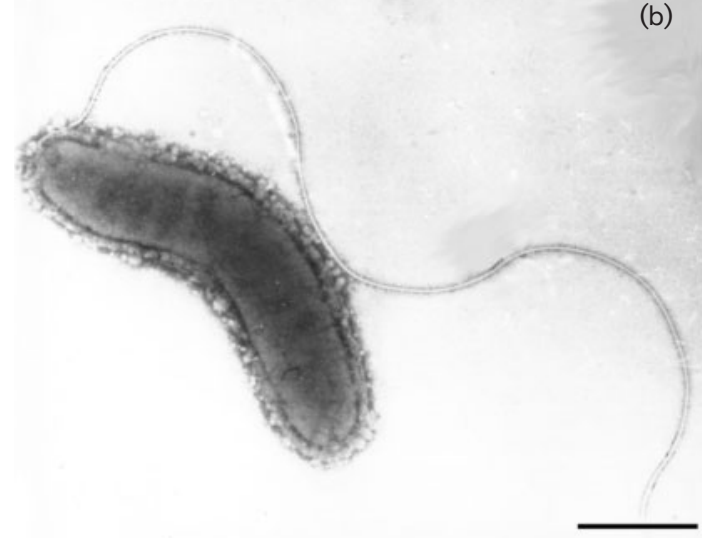

Fig. 1. Morphology of strain Z-7999 ${ }^{\top}$. (a) Cells as viewed by phase-contrast microscopy (bar, $10 \mu \mathrm{m}$ ). (b) Cell of strain Z-7999 ${ }^{\top}$ with polar flagellum (bar, $0.5 \mu \mathrm{m}$ ).

cells per chain). Cells exhibited rapid motility by means of one polar flagellum (Fig. 1b). Formation of spores was not observed. Organisms multiplied by binary fission. Gramstain was negative.

Strain Z-7999 ${ }^{\mathrm{T}}$ was an obligate anaerobe and grew only in anaerobically prepared medium where $\mathrm{O}_{2}$ was eliminated by boiling and addition of $\mathrm{Na}_{2} \mathrm{~S}_{1} 9 \mathrm{H}_{2} \mathrm{O}$. Growth of strain Z-7999 $9^{\mathrm{T}}$ occurred at temperatures of $15-40{ }^{\circ} \mathrm{C}$, with optimum growth at $35-38^{\circ} \mathrm{C}$. The $\mathrm{pH}$ range for growth was $6 \cdot 7-10 \cdot 3$, with optimum growth at $\mathrm{pH} 8 \cdot 0-9 \cdot 0$. Strain Z-7999 ${ }^{\mathrm{T}}$ grew in $\mathrm{NaCl}$ concentrations of $1-80 \mathrm{~g} \mathrm{l}^{-1}$, with optimum growth at $5-15 \mathrm{~g} \mathrm{NaCl} \mathrm{l}^{-1}$. Carbonate was required for growth.

Strain Z-7999 ${ }^{\mathrm{T}}$ grew with sulfate as an electron acceptor and molecular hydrogen, formate and lactate as electron donors. No growth was observed with the following electron donors: malonate, pyruvate, oxalate, malate, aspartate, succinate, glutamate, fumarate, acetate, butyrate, propionate, choline, betaine, methanol, ethanol, Casamino acids and yeast extract. Strain $\mathrm{Z}-7999^{\mathrm{T}}$ was not able to grow by a fermentative type of metabolism using sugars, peptone, yeast extract or pyruvate.
On basal medium with formate as the electron donor, strain Z-7999 ${ }^{\mathrm{T}}$ reduced sulfate, sulfite and thiosulfate, but did not reduce fumarate, dithionite, elemental sulfur, nitrate or nitrite. Strain Z-7999 ${ }^{\mathrm{T}}$ could grow lithotrophically with sulfate and molecular hydrogen as electron donor in the presence of acetate $\left(0 \cdot 16 \mathrm{~g} \mathrm{l}^{-1}\right)$ as carbon source. Lithotrophic growth of strain Z-7999 ${ }^{\mathrm{T}}$ was stable and did not decrease after three successive transfers on the same medium. Yeast extract was not required for growth and addition of yeast extract up to $1.5 \mathrm{~g} \mathrm{l}^{-1}$ did not stimulate growth of strain Z-7999 ${ }^{\mathrm{T}}$.

The DNA G + C content of strain $\mathrm{Z}-7999^{\mathrm{T}}$ was $56 \cdot 5 \pm$ $1 \mathrm{~mol} \%$. The almost-complete sequence of the 16S rRNA gene (1493 nt) of strain $\mathrm{Z}-7999^{\mathrm{T}}$, covering the region between position 33 and 1509 (E. coli numbering), was determined. The closest relatives of strain $\mathrm{Z}-7999^{\mathrm{T}}$ were Desulfonatronum thiodismutans $(95 \cdot 3 \%$ similarity) and Desulfonatronum lacustre $(95 \cdot 2 \%$ similarity). A comparative sequence analysis showed that the novel isolate belonged to the genus Desulfonatronum (Fig. 2) and the family 'Desulfonatronumaceae' within the order 'Desulfovibrionales' (Kuever et al., 2001). DNA-DNA hybridization of strain Z-7999 ${ }^{\mathrm{T}}$ with Desulfonatronum lacustre Z-7951 ${ }^{\mathrm{T}}$ $\left(=\right.$ DSM $\left.10312^{\mathrm{T}}\right)$ was $35 \pm 1 \%$.

The Gram-negative, alkaliphilic, sulfate-reducing bacteria include two genera: Desulfonatronovibrio and Desulfonatronum (Zhilina et al., 1997; Pikuta et al., 1998; Kuever et al., 2005). In contrast to monotypic Desulfonatronovibrio, the genus Desulfonatronum includes the species Desulfonatronum lacustre (Pikuta et al., 1998) and Desulfonatronum thiodismutans (Pikuta et al., 2003). These organisms oxidize molecular hydrogen, formate and ethanol during sulfate reduction and can also reduce sulfite and thiosulfate. Desulfonatronum lacustre has a lithoheterotrophic type of metabolism (Pikuta et al., 1998), whereas Desulfonatronum thiodismutans can grow lithoautotrophically using $\mathrm{CO}_{2}$ as the only carbon source (Pikuta et al., 2003). All of these species are obligate alkaliphiles that cannot grow below $\mathrm{pH} 8 \cdot 0$.

Phylogenetic analysis indicated that strain $\mathrm{Z}-7999^{\mathrm{T}}$ represents a novel species within the genus Desulfonatronum (Fig. 2). This is supported by several phenotypic differences between strain Z-7999 ${ }^{\mathrm{T}}$ and both described species of the genus Desulfonatronum. In contrast to Desulfonatronum lacustre and Desulfonatronum thiodismutans, cells of strain $\mathrm{Z}-7999^{\mathrm{T}}$ are thin and small (see Table 1). Strain Z-7999 ${ }^{\mathrm{T}}$ is able to grow over a $\mathrm{pH}$ range of $6 \cdot 7-10 \cdot 3$, whereas the $\mathrm{pH}$ range for growth of Desulfonatronum lacustre and Desulfonatronum thiodismutans is $8 \cdot 0-10 \cdot 0$ (Table 1 ). The tolerance to a lower $\mathrm{pH}$ and the broader $\mathrm{pH}$ range of the novel species might be linked to its ecological function. The ability to utilize organic acids in varying local $\mathrm{pH}$ values in microhabitats might require a broader $\mathrm{pH}$ tolerance. Strain Z-7999 ${ }^{\mathrm{T}}$ utilized molecular hydrogen, formate and lactate, but was unable to use ethanol, unlike the type strains of Desulfonatronum lacustre and Desulfonatronum 


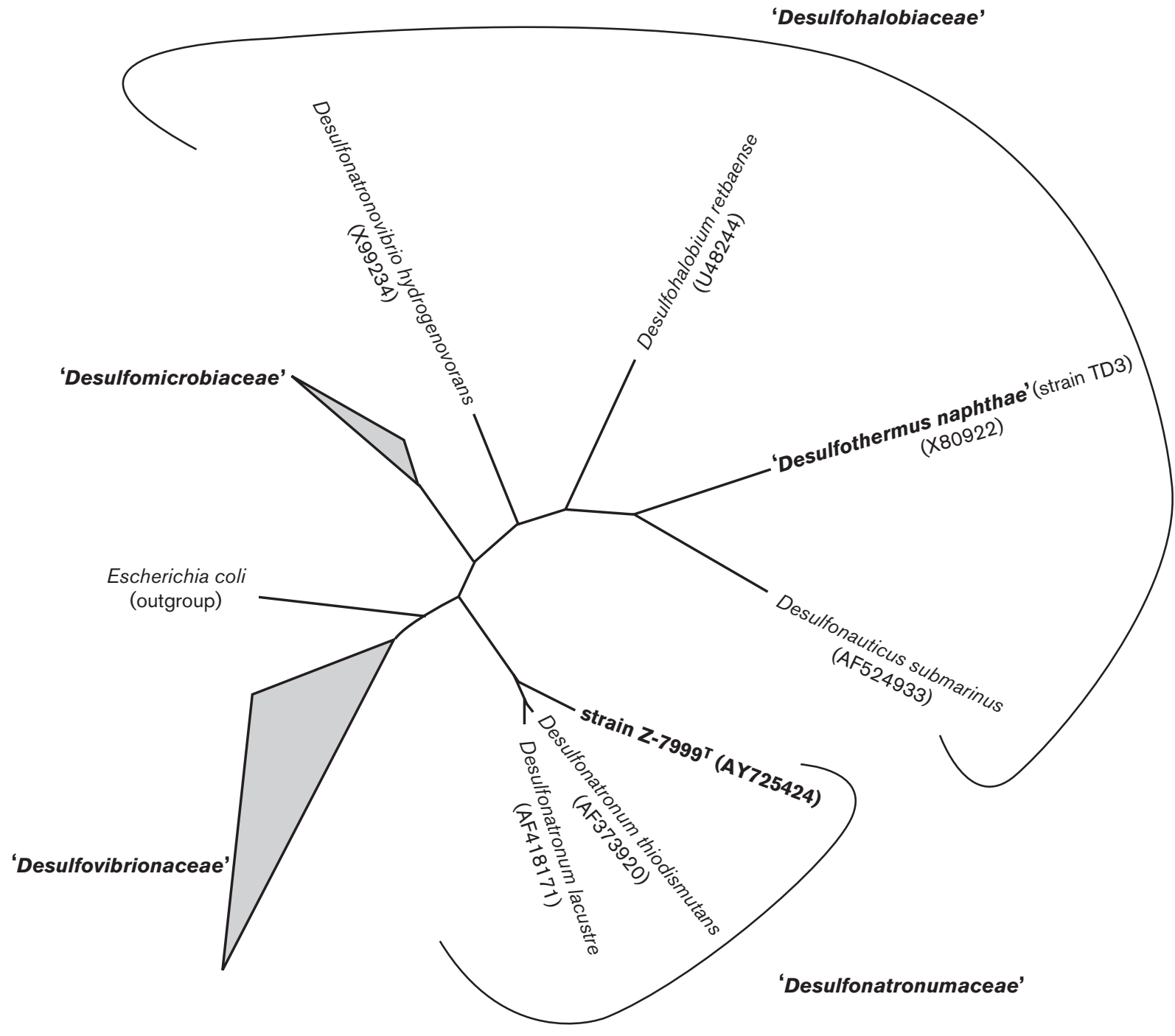

$10 \%$

Fig. 2. Phylogenetic tree showing the affiliation of the $16 \mathrm{~S}$ rRNA gene sequence from strain Z-7999 ${ }^{\top}$ to selected reference sequences and families of the $\delta$-Proteobacteria. The tree was calculated by maximum-likelihood analyses with termini filter. The following are type species: Desulfonatronovibrio hydrogenovorans, Desulfohalobium retbaense, Desulfonauticus submarinus and Desulfonatronum lacustre. Bar, $10 \%$ estimated sequence divergence.

thiodismutans, which were both able to oxidize ethanol (Table 1). The coupling of sulfidogenesis to lactate utilization has been demonstrated for the haloalkaliphilic community of the Tuva soda lakes in the past (Zavarzin et al., 1996). As a result, the lactate-oxidizing, alkaliphilic, sulfate-reducer Desulfonatronum lacustre strain Z-7955 has been isolated (Zhilina, 2005).

Thus, strain Z $-7999^{\mathrm{T}}$ could be characterized as a hydrogenotrophic, alkaliphilic, halotolerant species of the genus Desulfonatronum with a broad $\mathrm{pH}$ range for growth that is able to oxidize lactate, but not ethanol. On the basis of physiological properties and phylogenetic analysis, it is proposed that strain Z-7999 ${ }^{\mathrm{T}}$ represents a novel species in the genus Desulfonatronum, namely Desulfonatronum cooperativum sp. nov.

\section{Description of Desulfonatronum cooperativum sp. nov.}

Desulfonatronum cooperativum (co.op.er.at.i'vum. L. neut. adj. cooperativum cooperative).

Vibrioid cells, $0 \cdot 4-0 \cdot 5 \mu \mathrm{m}$ in diameter and $1 \cdot 0-2 \cdot 5 \mu \mathrm{m}$ in length, occurring singly or in chains. Cells exhibit rapid motility by means of one polar flagellum. Non-sporeforming. The cell wall has Gram-negative structure. Anaerobe. Alkaliphile with broad $\mathrm{pH}$ range for growth. 
Table 1. Characteristics that differentiate strain $Z-7999^{\top}$ from the type strains of other species of the genus Desulfonatronum

Taxa: 1, D. lacustre (Pikuta et al., 1998; Zhilina, 2005); 2, D. thiodismutans (Pikuta et al., 2003); 3, strain $\mathrm{Z}-7999^{\mathrm{T}}$.

\begin{tabular}{|lccc|}
\hline Characteristic & $\mathbf{1}$ & $\mathbf{2}$ & $\mathbf{3}$ \\
\hline Cell size $(\mu \mathrm{m})$ & $0 \cdot 7-0 \cdot 9 \times 2 \cdot 5-3 \cdot 0$ & $0 \cdot 6-0 \cdot 7 \times 1 \cdot 2-2 \cdot 7$ & $0 \cdot 4-0 \cdot 5 \times 1 \cdot 0-2 \cdot 5$ \\
Growth temperature $\left({ }^{\circ} \mathrm{C}\right):$ & $22-45$ & $15-48$ & $15-40$ \\
$\quad$ Range & 40 & 37 & $35-38$ \\
Optimum & & & \\
Growth pH: & $8 \cdot 0-10 \cdot 1$ & $8 \cdot 0-10 \cdot 0$ & $6 \cdot 7-10 \cdot 3$ \\
Range & $9 \cdot 3-9 \cdot 5$ & $9 \cdot 5$ & $8 \cdot 0-9 \cdot 0$ \\
Optimum & $0-100$ & $>10-70$ & $>10-80$ \\
Growth in $\mathrm{NaCl}\left(\mathrm{g}^{-1}\right):$ & 0 & 30 & $5-15$ \\
Range & $57 \cdot 3 \pm 1$ & $63 \cdot 1 \pm 1$ & $56 \cdot 5 \pm 1$ \\
Optimum & & & + \\
DNA G $+\mathrm{C}$ content $(\mathrm{mol} \%)$ & + & $+{ }^{*}$ & + \\
Electron donors with sulfate: & + & - & + \\
$\mathrm{H}_{2}$ & + & + & - \\
Formate & + & & + \\
Lactate & & & \\
Ethanol & & & \\
\end{tabular}

${ }^{*}$ Autotrophic growth.

$\dagger$ Although the type strain of D. lacustre did not utilize lactate, D. lacustre strain Z-7955 was able to grow with lactate (see Zhilina, 2005).

Growth occurs at $\mathrm{pH} 6 \cdot 7-10 \cdot 3$ and $15-40{ }^{\circ} \mathrm{C}$, with optimum growth at $\mathrm{pH} 8 \cdot 0-9 \cdot 0$ and $35-38{ }^{\circ} \mathrm{C}$. $\mathrm{Cl}^{-}$is not required for growth. Growth occurs with sulfate as an electron acceptor and molecular hydrogen, formate and lactate as electron donors with production of $\mathrm{H}_{2} \mathrm{~S}$. No growth occurs on malonate, pyruvate, oxalate, malate, aspartate, succinate, glutamate, fumarate, acetate, butyrate, propionate, choline, betaine, methanol, ethanol, Casamino acids or yeast extract. Unable to grow by fermentation of sugars, peptone, yeast extract or pyruvate. As well as sulfate, sulfite and thiosulfate are reduced to sulfide, but dithionite, elemental sulfur, nitrate, nitrite and fumarate are not used as electron acceptors with formate as electron donor. Grows lithotrophically with sulfate as electron acceptor and molecular hydrogen as electron donor in the presence of acetate as carbon source.

The type strain is $\mathrm{Z}-7999^{\mathrm{T}}\left(=\mathrm{DSM} 16749^{\mathrm{T}}=\mathrm{VKM}\right.$ B$\left.2329^{\mathrm{T}}\right)$. The DNA $\mathrm{G}+\mathrm{C}$ content of the type strain is $56 \cdot 5 \pm 1 \mathrm{~mol} \%$. Isolated from syntrophic acetatedecomposing culture enriched from anaerobic deposits of soda lake Khadin, Tuva, Russia.

\section{Acknowledgements}

This work was supported by the Hanse Institute for Advanced Study during a stay in Germany of T.N.Z. and G.A.Z., the Program MCB PAS and the Research Program of Presidium PAS 'Archean-proterozoic microbial communities and their present-times analogues'.

\section{References}

Garnova, E. S., Zhilina, T. N., Tourova, T. P. \& Lysenko, A. M. (2003). Anoxynatronum sibiricum gen. nov., sp. nov. - alkaliphilic saccharolytic anaerobe from cellulolytic community of Nizhnee Beloe (Transbaikal region). Extremophiles 7, 213-220.

Gorlenko, V. M., Namsaraev, B. B., Kulyrova, A. V., Zavarzina, D. G. \& Zhilina, T. N. (1999). The activity of sulfate-reducing bacteria in bottom sediments of soda lakes of the Southeastern Transbaikal Region. Microbiology (English translation of Mikrobiologiya) 68, 580-585.

Kevbrin, V. V. \& Zavarzin, G. A. (1992). The effect of sulfur compounds on growth of the halophilic homoacetic bacterium Acetohalobium arabaticum. Microbiology (English translation of Mikrobiologiya) 61, 563-567.

Kevbrin, V. V., Zhilina, T. N. \& Zavarzin, G. A. (1999). Decomposition of cellulose by the anaerobic alkaliphilic microbial community. Microbiology (English translation of Mikrobiologiya) 68, 601-609.

Kuever, J., Könneke, M., Galushko, A. \& Drzyzga, O. (2001). Reclassification of Desulfobacterium phenolicum as Desulfobacula phenolica comb. nov. and description of strain $\operatorname{Sax}^{\mathrm{T}}$ as Desulfotignum balticum gen. nov., sp. nov. Int J Syst Evol Microbiol 51, 171-177.

Kuever, J., Rainey, F. A. \& Widdel, F. (2005). Family Desulfonatronumaceae fam. nov. In Bergey's Manual of Systematic Bacteriology, 2nd edn, vol. 2. Edited by G. M. Garrity. New York: Springer (in press).

Ludwig, W., Strunk, O., Westram, R. \& 29 other authors (2004). ARB: a software environment for sequence data. Nucleic Acids Res 32, 1363-1371.

Marmur, J. (1961). A procedure for the isolation of deoxyribonucleic acid from microorganisms. J Mol Biol 3, 208-218. 
Owen, R. J., Hill, L. R. \& Lapage, S. P. (1969). Determination of DNA base composition from melting profiles in dilute buffers. Biopolymers 7, 503-516.

Pikuta, E. V., Zhilina, T. N., Zavarzin, G. A., Kostrikina, N. A., Osipov, G. A. \& Rainey, F. A. (1998). Desulfonatronum lacustre gen. nov., sp. nov.: a new alkaliphilic sulfate-reducing bacterium utilizing ethanol. Microbiology (English translation of Mikrobiologiya) 67, 123-131.

Pikuta, E. V., Hoover, R. B., Bej, A. K., Marsic, D., Whitman, W. B., Cleland, D. \& Krader, P. (2003). Desulfonatronum thiodismutans sp. nov., a novel alkaliphilic, sulfate-reducing bacterium capable of lithoautotrophic growth. Int J Syst Evol Microbiol 53, 1327-1332.

Rigby, P. W. S., Dieckman, M., Rhodes, C. \& Berg, P. (1977). Labeling deoxyribonucleic acid to high specific activity in vitro by nick-translation with DNA polymerase I. J Mol Biol 113, 237-251.
Trüper, H. G. \& Schlegel, H. G. (1964). Sulfur metabolism in Thiorhodaceae. Quantitative measurements on growing cells of Chromatium okenii. Antonie van Leeuwenhoek 30, 225-238.

Zavarzin, G. A. \& Zhilina, T. N. (2000). Anaerobic chemotrophic alkaliphiles. In Journey to Diverse Microbial Worlds, pp. 191-208. Edited by J. Seckbach. Dordrecht: Kluwer Academic.

Zavarzin, G. A., Zhilina, T. N. \& Pikuta, E. V. (1996). Secondary anaerobes in haloalkaliphilic communities in lakes of Tuva. Microbiology (English translation of Mikrobiologiya) 65, 480-486.

Zhilina, T. N. (2005). Genus Desulfonatronum. In Bergey's Manual of Systematic Bacteriology, 2nd edn, vol. 2. Edited by G. M. Garrity. New York: Springer (in press).

Zhilina, T. N., Zavarzin, G. A., Rainey, F. A., Pikuta, E. V., Osipov, G. A. \& Kostrikina, N. A. (1997). Desulfonatronovibrio hydrogenovorans gen. nov., sp. nov., an alkaliphilic, sulfate-reducing bacterium. Int J Syst Bacteriol 47, 144-149. 